Article

\title{
The Specificity of Family Firms Providing Accommodation Services-The Experience of a Post-Socialist Country 30 Years after the Economic Transformation
}

\author{
Hanna Górska-Warsewicz ${ }^{1, * \mathbb{D}}$, Maciej Dębski ${ }^{2} \mathbb{D}$, Krystyna Rejman ${ }^{1} \mathbb{D}$ and Wacław Laskowski $^{1}$ \\ 1 Department of Food Market and Consumer Research, Institute of Human Nutrition Sciences, \\ Warsaw University of Life Sciences, 02-787 Warsaw, Poland; krystyna_rejman@sggw.pl (K.R.); \\ waclaw_laskowski@sggw.pl (W.L.) \\ 2 Department of Marketing and Tourism, Faculty of Management and Security Sciences, \\ University of Social Sciences, 00-842 Warsaw, Poland; mdebski@san.edu.pl \\ * Correspondence: hanna_gorska_warsewicz@sggw.pl
}

Received: 10 November 2020; Accepted: 10 December 2020; Published: 12 December 2020

check for updates

\begin{abstract}
This study aimed to analyze the conditions and specificity of family firms (FFs) providing accommodation services in Poland 30 years after the beginning of economic changes. The research was carried out between 2017 and 2018 using the Computer-Assisted Website Interview (CAWI) method. In two stages of research, a total of 1300 questionnaires were sent to FFs providing accommodation services, and we received 83 fully completed questionnaires. This response rate indicates that there is still a lack of trust among FFs as a result of the activities of the socialist economy, which was negative towards private property. The respondents were generally business owners, but several questionnaires were completed by other members of the families running an accommodation service business. All companies participating in the survey provided their services in small towns or rural areas. In the structure of the surveyed FFs by type, guesthouses and lodgings had the largest share, and, in terms of location, FFs from the southern part of the country dominated. We found out that familiarity is an important feature of the Polish FFs providing accommodation services. The majority of FF representatives agreed that focusing on the specifics of family business allows them to compete with companies providing accommodation services. They also pointed out the long-term perspective of business and development and the provision of high-quality services. Such an approach is now possible because the period of a centrally planned economy had to be followed by a change in the way of thinking related to business activity in Poland.
\end{abstract}

Keywords: familiarity; family firms; accommodation services; sustainable development

\section{Introduction}

Family firms (FFs) (the terms "family firm" and "family business" are used synonymously throughout this article) are a traditional way of conducting business, attracting attention in public and political discussions. This interest is driven by greater awareness of their contribution to economic and social development, the issue of business transfers, as well as a higher degree of scientific interest [1]. Moreover, the importance of family business research is still growing, and this area remains an emerging field of research, beginning with defining FFs [2,3], establishing their identity $[4,5]$ and analyzing the conditions of their operation [6-8]. The success factors of FFs are analyzed in detail, including the management of the interrelationship between family concerns and business concerns, strong leadership and building of a culture that accepts continuous change [9]. The literature 
highlights the differences between FFs and non-FFs, including the role of the family [10-12], family ownership [13-15], family capital [16], family social capital [17], the socio-emotional wealth [14,18-20], social responsibility $[13,21]$ as well as firm performance [22,23], firm outcomes and results [13-15]. Other issues are also analyzed, particularly those related to sustainable development [11], the strategic advantage in relation to resource-based management [24], the strategic management $[8,25,26]$, brand building [27,28], risk management and image creation [15]. An interesting approach is applied to the transfer from family identity to family firm image and reputation [29].

Most FFs in Poland were established after 1989 [30]. The specific situation of FFs in Poland results from the long period of staying in the area of a centrally planned economy, where the preferred owner was the state. Large industrial factories, 5-year economic plans, and the closure of the Polish economy to western influences were not conducive to the development of FFs, and constituted a barrier to their development. An additional aspect was the unfavorable or even hostile treatment of private property by the state authorities [31]. It was the political and economic changes initiated in 1989 that created opportunities for the development of companies based on private property [32]. According to Family Business Network Poland, there are currently over one million family businesses in Poland. They generate over $18 \%$ of the GDP and create the most jobs, determining stable employment on a national scale. After 30 years of activity of Polish family businesses, the need for succession arises [33].

Taking into account these circumstances, we have undertaken research on the factors related to the functioning of FFs in the selected area of business activity, i.e., accommodation services. The choice of this sector was based on the authors' interests and the importance of this area of activity for the sustainable development of Poland, especially for post-industrial areas after the closure of large state-owned plants, including steel mills, mines and machinery manufacturing plants for all countries of the Central and Eastern Europe (CEE) block.

\section{Literature Overview}

\subsection{Family Firms-General Overview}

According to the best available research, the importance of family business has been equated to: 1-GDP: in most countries worldwide, they account for $60-90 \%$ of the non-governmental sector's GDP; 2 -jobs: in most countries worldwide, they account for $50-80 \%$ of all jobs in the private sector; 3-start-ups: $85 \%$ of all business start-ups start with family money; 4 -employment growth: in the US, family business account for more than $75 \%$ of the net employment growth; 5 -weighting: in most countries worldwide, FFs account for from 70 to $95 \%$ of all businesses [34].

FFs are the most common form of business organisation in Europe [6]. In the whole of Europe, about $70-80 \%$ of enterprises are FFs (the smallest share is in Lithuania, Latvia and Sweden, with less than $60 \%$; the highest in Estonia, Slovakia and Cyprus-90\%). They account for about $40-50 \%$ of employment, providing over 60 million jobs in the private sector [1]. According to the EY Family Business Yearbook 2014, 85\% of all European companies are FFs and these account for $60 \%$ of jobs in the private sector [35]. The sector of FFs is dominated by SMEs (Small- and Medium-Sized Enterprises), and particularly by micro-enterprises with less than 10 employees. However, some of the largest European companies are also family businesses [1]. Of the world's 500 largest family businesses, $44.8 \%$ (224) are located in Europe [36]. Arguably, the most defining features of family businesses are the ownership aspects, as they are crucial to the business life of the firm [34].

Despite the considerable economic significance of FFs and the growing number of studies on this group of companies, there is no commonly accepted definition of a family business [2]. Most of the scientific literature on family business (and proposals for definitions) has been developed in the North American context $[37,38]$. Due to the internal diversity of existing definitions, it is difficult to propose a clear definition of a family business [9]. Experts from the Family Firms Institute agree that there is no single definition and that the key to the discussion is to know what definition is used. However, they propose that an FF is one in which many members of the same family are involved as major 
owners or managers, either contemporaneously or over time. This allows for many variants in terms of the level of ownership and control over voting, the managerial roles played by family members, and the key family members [37].

To date, there is no legally binding, concrete, simple and harmonised Europe-wide definition of a family business [38]. Within the European Commission, an international research project (with the participation of representatives of all Member States) has established that, despite the differences in definitions, there are three essential elements characterising this form of business activity: family, company, and ownership. The expert group proposes that a firm, regardless of its size, is a family business if [39]:

1. Most decision-making rights are held by the individual(s) who founded the firm, or by the individual(s) who acquired the share capital of the firm, or by their spouses, parents, children or direct heirs of children;

2. Most decision-making rights are indirect or direct;

3. At least one family member or relative is formally involved in the management of the firm;

4. Listed companies meet the definition of a family business if the person who founded or acquired the firm (share capital) or their families or descendants possess $25 \%$ of the decision-making rights mandated by their share capital.

However, this definition is not legally binding and more than 90 different definitions of a family business are used in individual Member States [40]. Among the most commonly used definition criteria, ownership or management criterions prevail. There are also definitions that take into account the involvement (of family members) in business and those that combine more than one criterion. There are also definitions taking into account succession as an indispensable criterion of belonging to a group of family companies [30]. In Poland, the Initiative of Family Companies focuses on ownership and management when defining FF. According to these criteria, the majority of the capital and the intention to maintain ownership is within the family, and at least one family member holds a managerial position or has a significant influence on the management [1]. Another definition proposed by the Polish academic community is that it is the business entities are managed in accordance with the value system and ethical and moral standards of the business families that established or acquired them in order to provide financial security for their current and future members [41].

The world scientific literature offers many definitions of an FF, e.g., it is defined as an enterprise that is managed and/or directed with the intention to shape and realize its vision and is owned by a dominant coalition controlled by members of the same family or a small number of families in a potentially sustainable way by generations of family or families [3]. This type of firm, with a unique working environment, encourages the creation of family jobs and inspires greater care and loyalty to employees [24,42]. In this context, the specificity of FFs can be defined as familiness, considered in terms of a resource-based perspective [24,43]. In the literature, familiness is described as a bundle of resources that are distinctive of a firm as a result of family involvement as well as the unique bundle of resources a particular firm has because of the system's interaction between the family, its individual members, and the business [24]. It is perceived as a combination of existing resources of social, human, financial, and physical capital in a firm, resulting from interactions between family and business systems [24]. In this respect, there are three elements of familiness: human resources (reputation and experience), organizational resources (decision-making and learning), and process resources (relationships and networks) [44]. Familiness perspectives include financial perspectives (incentives for the retiring generation), customer size (family brand and image), internal processes (family philanthropic activities), learning and development (career paths for family members) [44].

A characteristic feature of FFs is the involvement of the family in ownership and/or management, considered as an unique resource [23,45]. This is treated as the specific result of the structural relationship between the family and the enterprise, which can evoke a specific identity as an FF [46]. The literature underlines the importance of family values, which become values in the enterprise. In this 
aspect, FFs are seen as more trustworthy or honest than other types of business [47]. The relationship between communication of the family nature of the company and trust $[47,48]$ is reflected in the specific identity and image of FFs [29] as having reputation-based advantages over non-FFs [4,24,45].

An important aspect of the uniqueness of FFs is social capital $[4,21,49]$ analyzed from two perspectives: the family and the organizational social capital. They are considered to be hybrid organizations with interpermeating identities of the family and the company [50]. It is noted that many FFs operate to achieve family goals, e.g., family unity, continuity, and employment of family members, even at the cost of profit maximization [51,52]. Additionally, family social capital influences the development of organizational social capital through the following mechanisms: institutional isomorphism of the family institution, organizational identity and rationality, human resource practices, and overlapping social networks [49].

FFs are also characterized by sustainable development $[3,12,21]$, based on sustained competitive advantage [24], long-term management perspective [21,43], more personalized control [53] or strong attachment to the local market [27]. At the same time, sustainability is determined by the combination of available resources and limitations from family and business. In this case, sustainability results from a combination of family success, business success and the ability to respond to disturbances [11].

The above-mentioned elements become the basis for building brand strategies, defined in the literature as family-based branding strategies considered in two ways: (1) family name used as a brand at the corporate level (family as a corporate brand) and as a name at the product level (family as a product brand) [23]. In this respect, the greater motivation of owners trying to ensure a good reputation of the company is important [54]. In branding strategies, the family-based brand identity is perceived as a unique and essential part of the resources and capabilities of a family business [55]. This is reflected in the building of relationships with customers and other stakeholders [21], which is an important element of business strategies [56-59].

\subsection{Family Firms Providing Accommodation Services}

The family nature of businesses is important in tourism, which is related to the service nature and the specificity of tourist companies. First of all, family capital in tourism is relatively immobile. Owners, due to their origin, are strongly connected with a given region and, consequently, there is a high probability of investing in a given area $[28,60]$. It is suggested that links with the local community enrich the FF's Socio-Emotional Wealth (SEW) [61]. They recognize the benefits of the positive environmental and social effects [62], and the sense of ownership motivates SMEs in tourism to engage in eco-friendly behavior [63], even exceeding those dictated by law [53].

However, there are studies indicating that despite the links with local communities, family tourist firms are reluctant to implement sustainable practices [51]. This shows a direct link between CSR practices and positive enterprise results [64], and their reputation and perception [65].

In the tourist market, being an FF becomes an important part of the tourist experience of the guests [28] in the context of the unique intangible resources that contribute to an FF's uniqueness $[28,60]$. In post-socialist countries, i.e., Poland, FFs providing accommodation services are in the group of small enterprises which are an important element of the development of tourism, based on reference to nature, and sustainable development. In Poland, this is largely related to the activation of the population in the eastern and southern parts of the country, where, after a period of centrally planned economy, there was no large industry and the local population was looking for other business opportunities.

\subsection{Research Gap and the Scope of Research}

Although familiness is an important topic for tourism FFs, there is very little research on familiness from the perspective of the consumer or in tourism firms [28,60]. In particular, this concerns Poland, and the published studies refer to a theoretical analysis of the issue of FFs, with a small number of articles based on case studies [30,66-69]. Studies of larger samples are rare due to the fact that the possibility of the development of FFs has been present in Poland since 1989. There are also no 
studies conducted among FFs providing accommodation services. An additional aspect that makes the development of FFs providing accommodation services in Poland difficult is the very high seasonality, the temporary preferences of Poles to spend their holidays abroad and the still unsatisfactory quality of accommodation services provided by FFs.

Therefore, the aim of this study was to analyze the conditions and specific features of FFs providing accommodation services in Poland 30 years after the beginning of the economic changes. We paid special attention to the importance of stakeholders, familiarity and other features determining the activity of FFs providing accommodation services. This is the second part of the research and a continuation of our previous analyses. The first part referred to the brand identifiers, brand importance and brand management of FFs providing accommodation services. We analyzed the customer-based brand equity of FFs, and this concept was presented at the international tourism conference in Karpacz, Poland and published [70].

\section{Materials and Methods}

\subsection{General Overview}

The aim of this study was to analyze the conditions and specificity of FFs providing accommodation services in Poland 30 years after the beginning of economic changes. We drew attention to the specific conditions of such an area of economic activity, including the importance of stakeholders in the family and the features highlighted in the promotion of accommodation services provided by FFs.

\subsection{Ethical Principles}

The research was carried out in accordance with the ethical principles related to an enterprise understood in accordance with article $55^{1}$ of the Polish Civil Code [71]. According to this law regulation, an enterprise is an organized set of eight tangible and intangible elements intended for conducting business activity and subject to protection. One of these protections is the confidentiality of the enterprise, therefore our survey assumed full anonymity.

\subsection{Study Design}

The research was carried out in 2017-2018 on a sample of 83 family firms. The criterion for participation in the survey was running a family business in the accommodation services sector in Poland. The respondents were generally business owners, but we also received several questionnaires completed by another family member. All companies participating in the survey provided their services in small towns or villages. The structure of the sample is appropriate for the number of guesthouses, lodgings and agritourist farms by the main voivodships in Poland [72-84].

This research area (FFs providing accommodation services) is a difficult research area in Poland, as evidenced by the fact that even the large study commissioned by the Polish government in 2007-2008, with a total sample of 1610 FFs, included only 64 companies providing catering and accommodation services. Of this group of FFs providing accommodation services, there were only about 50\%, that is, 32 [30]. This indicates that, in Poland, surveys among entrepreneurs from FFs in the sector of accommodation services are rare due to difficulties in sample selection. This is primarily due to reluctance to participate in the surveys, fear of competition, etc. In the Polish literature, there are studies based on case studies [19] or conducted among consumers (tourists) visiting family businesses [45]. This issue is widely analyzed in the world literature referring to political, economic and social barriers [85].

The sample size from our study is comparable to other studies published in the scientific literature on family businesses [13,23,86-92]. They relate to various sectors and areas of business activity, while our research concerns only FFs providing accommodation services. Examples of research samples in scientific literature are as follows: 114 of FFs [23], 59 of FFs and 202 of non-FFs [13], 92 of 
Spanish FFs [86], 65 of fast-growth FFs [87], 92 of the world's oldest FFs [89], 100 FFs vs. 75 non- FFs [90], 71 FFs vs. 99 non-FFs [92], or 102 FFs [91].

The sample selection had two stages. In the first stage, electronic questionnaires were sent to 980 FFs providing accommodation services from own database. This database was created by the authors as a result of previous research. In the second stage of the research, we asked regional tourism organizations (TOs) to distribute the questionnaires. These included Dolnoślaska TO, Kujawsko-Pomorska TO, Lubelska Regional TO, Lubuska Regional TO, Małopolska TO, Śląska TO, Wielkopolska TO, Mazowiecka Regional TO, Opolska Regional TO, Podkarpacka Regional TO, Podlaska Regional TO, Pomorska Regional, Regional TO of Łodź Voivodeship, Regional TO of Świętkorzyskie Voivodeship, Zachodniopomorska Regional TO, Warminsko-Mazurska TO. A total of 1300 questionnaires were sent to FFs providing accommodation services, and we received 83 fully completed questionnaires; the response rate was $8 \%$. The topic of response rate and non-response bias is widely analyzed in the literature [85,93-95]. The response rate in our research is comparable to the other enterprise surveys analyzed. The literature on the subject emphasizes that the average response rate in organizational research studies will continue to decline with time. The minimum response rate in a systematic literature review is given as 3\% [93].

We have adopted the Computer-Assisted Website Interview (CAWI) method as our research method. It was important to ensure anonymity and to guarantee to the participants that the results will be used for scientific purposes.

\subsection{Questionnaire Design}

The questionnaire consisted of four parts (Table 1), but in this study we limited the analysis to data obtained from two parts. The first part characterized the surveyed FFs in terms of the number of people employed, location and type of activity. The second part concerned the specificity of FFs, including the importance of familiarity, the roles of stakeholders, and the factors determining the management of family businesses. While constructing the scales, we took into account the statements and results published in the scientific literature $[10,21,24,42,96,97]$ as well as our previous experience of conducting research in this specific area of the tourism services sector.

Table 1. Questionnaire structure.

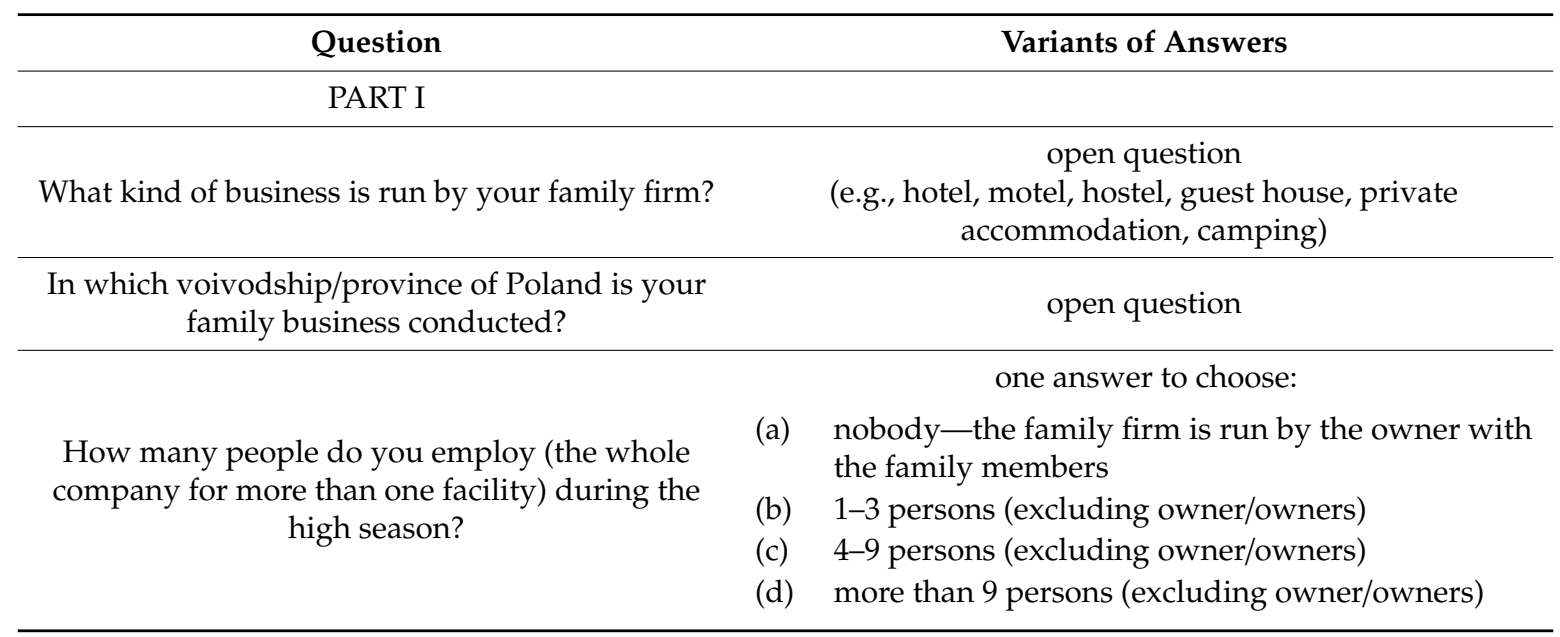


Table 1. Cont.

\begin{tabular}{|c|c|}
\hline Question & Variants of Answers \\
\hline Please specify the characteristics of your company & $\begin{array}{l}\text { yes or no answer: } \\
\text { Is your company owned by } 1 \text { person or } 1 \text { family? } \\
\text { If your company is owned by } 1 \text { family, is more than } 1 \\
\text { person from the family involved in the business? }\end{array}$ \\
\hline \multicolumn{2}{|l|}{ PART II } \\
\hline \multirow{3}{*}{$\begin{array}{c}\text { Please evaluate the following statements } \\
\text { regarding your family business } \\
\text { Please rate on a scale: } \\
\text { totally agree, agree, neither agree nor disagree, } \\
\text { disagree, totally disagree }\end{array}$} & $\begin{array}{l}\text { - In building the company's image we take into } \\
\text { account its family character }\end{array}$ \\
\hline & $\begin{array}{l}\text { - The limitation for marketing activity is financing the } \\
\text { needs of the family from the profit gained from the } \\
\text { business activity }\end{array}$ \\
\hline & $\begin{array}{l}\text { - Family character, hospitality and specific mood of } \\
\text { our object allow to compete with larger facilities of } \\
\text { higher standard }\end{array}$ \\
\hline $\begin{array}{l}\text { Please assess on a scale from } 1 \text { to } 5 \text { the importance } \\
\text { of the family nature of the company for different } \\
\text { stakeholder groups (1-not relevant, } 5-\text { crucial })\end{array}$ & $\begin{array}{ll}\text { - } & \text { Customers/individual guests } \\
\text { - } & \text { Other entrepreneurs from the same local area } \\
\text { - } & \text { Business customers (if any) } \\
\text { - } & \text { Local authorities } \\
\text { - } & \text { Suppliers of products or services } \\
\text { - } & \text { Employees (if any) } \\
\text { - } & \text { Family members } \\
\text { - } & \text { Other }\end{array}$ \\
\hline
\end{tabular}

We have a long-term development strategy, to which we subject current decisions

The limitation for marketing activities is the lack of funds

The limitation for marketing activities is the lack of knowledge and skills, e.g., in the field of promotion

Please evaluate the following statements regarding your family business

Please rate on a scale:

totally agree, agree, neither agree nor disagree, disagree, totally disagree

We try to distinguish ourselves by the quality of service and hospitality

We conduct surveys of customer expectations

A small enterprise has very limited possibilities to compete in terms of quality with large facilities

We focus on current activities, current problems and tasks make it impossible for us to look ahead

\begin{tabular}{cl}
\hline PART III Promotion and Name & not analyzed in this study \\
\hline PART IV Brand Meaning & not analyzed in this study \\
\hline
\end{tabular}

Many issues concerning the activity of Polish FFs are considered only theoretically or by case study, so we included them in our research. These concern, e.g., the limitations of marketing activities. Additionally, this aspect is taken up in theoretical studies describing Polish FFs.

\subsection{Statistical Analysis}

The quantitative data were analyzed using the STATISTICA software package (StatSoft Inc., Copyright 1984-2917, TIBCO Software Inc., Palo Alto, CA, USA) We divided the sample of FFs into three clusters for every analyzed question using the Kohonen Neural Network [98] as the market research data classification by means of artificial Neural Networks algorithms [99]. We applied cluster analysis as a technique of grouping similar observations into several clusters $[100,101]$ to analyze the 
familiarity and family character of FFs as specific features of FFs providing accommodation services, features of the FF activities in accommodation services, the importance of the familiarity of FFs providing accommodation services for different stakeholder groups and specific features underlined in promotional activities by FFs providing accommodation services. In each cluster, we presented the structure by type of business activities, including guest houses, lodgings, agritourist farms and others.

\subsection{Sample Population}

Table 2 presents the characteristics of the surveyed FFs. In the structure of the studied FFs, the largest share was held by guest houses and lodgings, and in terms of location, the highest share of responses was from the southern part of the country.

Table 2. Sample structure.

\begin{tabular}{cc}
\hline Specification & Percentage of Sample \\
\hline Type of business activities & \\
\hline guest houses & \\
lodgings & $34.90 \%$ \\
agritourist farms & $31.30 \%$ \\
others (holiday centers, inns, summer rental houses, hotels and & $15.70 \%$ \\
short-term studio apartments) & $18.10 \%$ \\
\hline Location (voivodships/province) & \\
\hline małopolskie & \\
Sląskie & $21.70 \%$ \\
dolnoślaskie & $19.30 \%$ \\
warmińsko-mazurskie & $15.70 \%$ \\
pomorskie & $12.00 \%$ \\
zachodniopomorskie & $9.60 \%$ \\
others (mazowieckie, podlaskie, kujawsko-pomorskie, łódzkie) & $8.40 \%$ \\
\hline Family nature of enterprises providing accommodation services & $6.00 \%$ \\
\hline it is the property of one person or one family & $7.30 \%$ \\
more than one person is involved in the activity of the company, & \\
because it is family property & $68.00 \%$ \\
\hline
\end{tabular}

\section{Results}

\subsection{Familiarity as a Specific Feature of FFs Providing Accommodation Services}

The familiarity and family character as the specific features of FFs are presented in Table 3. Nearly $80 \%$ of the FFs surveyed agreed or totally agreed with the statement "family character, hospitality and specific mood of our object allow to compete with larger facilities of higher standard" (average value was 1.08). The next statement "in building the company's image we take into account its family character" was totally accepted or accepted by almost $70 \%$ of the surveyed FFs (mean value 0.88 ). In order to present the familiarity as a specific feature of FFs, a cluster analysis was conducted, distinguishing three groups of FFs. For FFs from cluster no. 1 and no. 2, the familiarity was the basis for building the image of the company (average value around 1). At the same time, it allowed to compete with larger companies operating in the sector of accommodation services (average value around 1.5). 
Table 3. Familiarity and family character of FFs as specific features of FFs providing accommodation services.

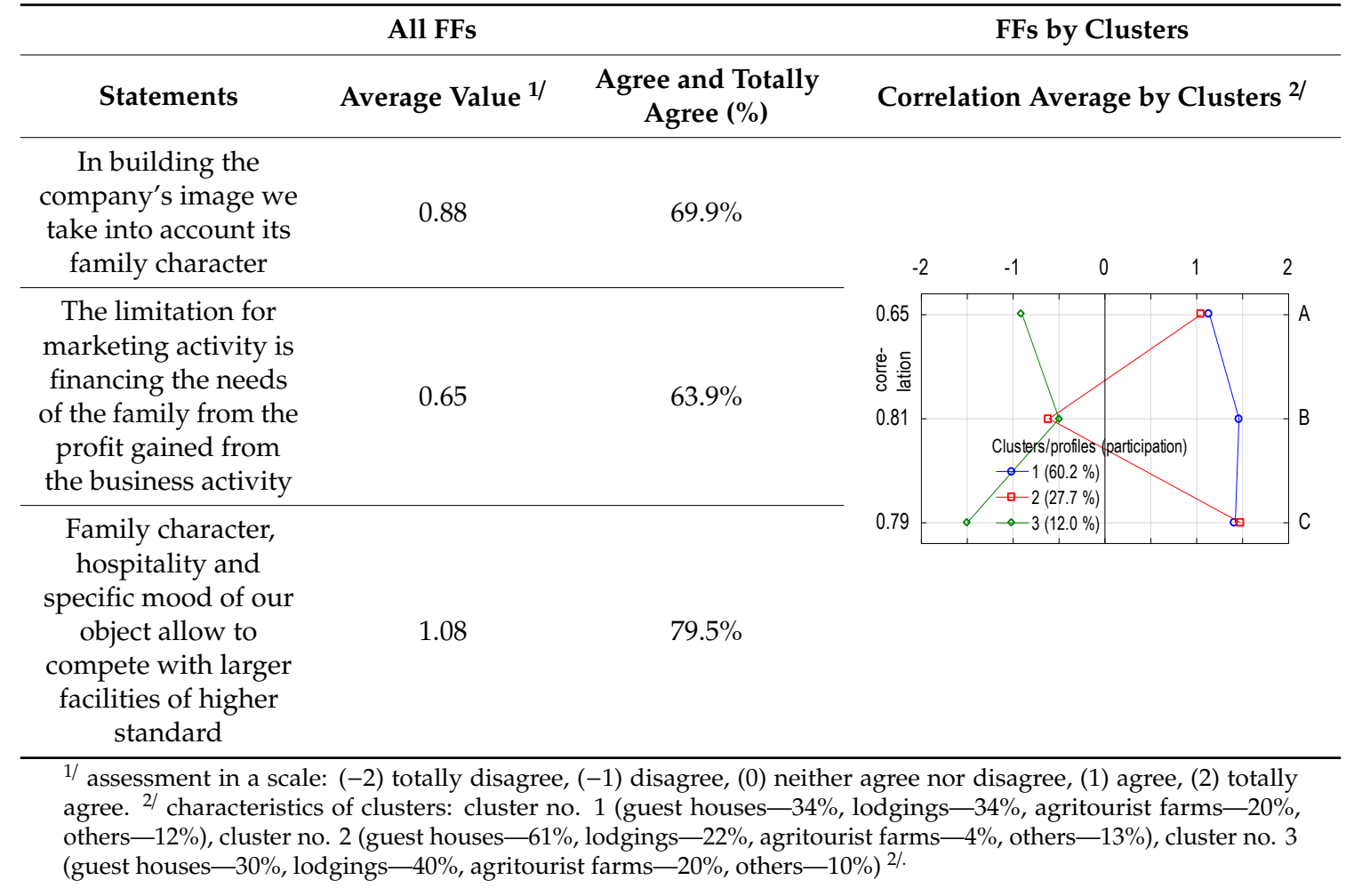

\subsection{Other Specific Features of FFs Providing Accommodation Services}

Other specific features of FFs in the Polish sector of accommodation services are presented in Table 4. The surveyed FFs most often agreed totally or agreed with the statement: "we try to distinguish ourselves from larger companies by the quality of service and hospitality". The average value for this statement, on a scale from -2 to 2 , for all surveyed FFs was 1.49 , while in cluster no. 1 it was almost 2 , and in cluster no. 2 it was almost $1.5(p<0.05)$. The statement "we have a long-term development strategy, to which we subject current decisions" was ranked second in terms of average value (the average for all FFs was 0.94 , for FFs from cluster 1 and 2, it oscillated around 1).

The representatives of the FFs agreed with the statements to the least extent: "the limitation for marketing activities is the lack of knowledge and skills e.g., in the field of promotion" and "we focus on current activities, as current problems and tasks hold us back from looking ahead" (average -0.11 and -0.02 respectively). Almost $40 \%$ of the FFs' representatives agreed or agreed totally with these statements.

Another issue we investigated was the importance of stakeholders in the activities of FFs providing accommodation services (Table 5). The greatest importance was attributed to family members (mean score of 4.22 on a scale from 1 to 5 , where 1 is not relevant and 5 is crucial). Nearly $80 \%$ of the respondents $(78.3 \%)$ gave this group of stakeholders a score of 4 or 5 , which indicates that this group of stakeholders is very important in running a family business providing accommodation services. Cluster analysis confirmed the importance of family members; in all three clusters the importance of family members was rated very high (average above 4 ). 
Table 4. Features of the FFs activities in accommodation services.

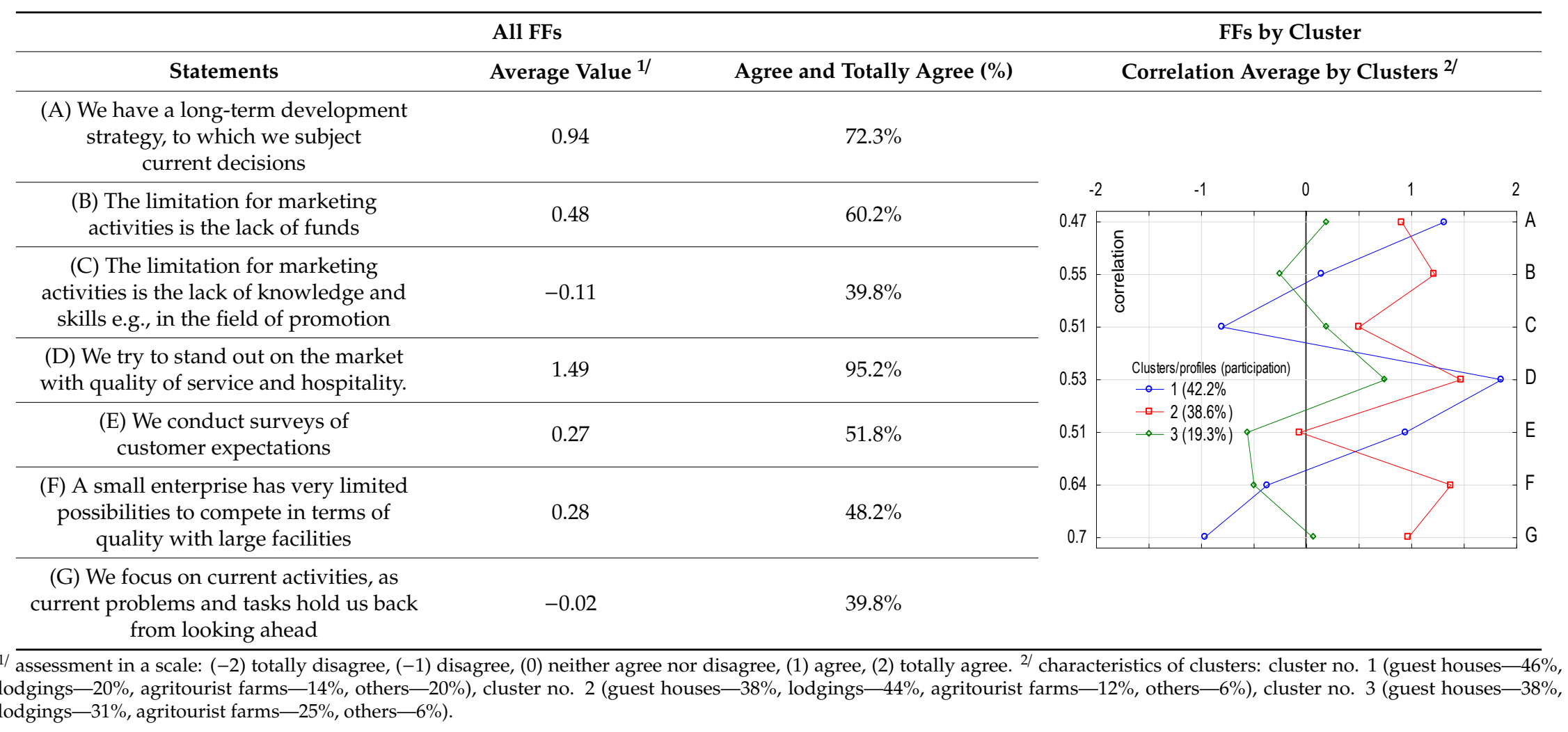


Table 5. The importance of familiarity of FFs providing accommodation services for different stakeholder groups.

\begin{tabular}{|c|c|c|c|c|c|c|c|c|c|c|c|}
\hline Statements & Average Value $^{1 /}$ & Notes: 4 and $5(\%)$ & \multicolumn{9}{|c|}{ Correlation Average by Clusters $2 /$} \\
\hline (A) Customers/individual guests & 3.79 & $67.5 \%$ & \multirow{2}{*}{$\begin{array}{r}1.0 \\
0.67\end{array}$} & 1.5 & 2.0 & 2.5 & 3.0 & 3.5 & 4.0 & \multirow{2}{*}{$\frac{4.5}{0}$} & 5.0 \\
\hline (B) Other entrepreneurs from the same local area & 2.52 & $19.3 \%$ & & & & & & & is & & $\nabla^{\mathrm{A}}$ \\
\hline (C) Business customers (if any) & 2.19 & $19.3 \%$ & 0.49 & & & & & & & participation & n) \\
\hline (D) Local authorities & 2.19 & $15.7 \%$ & 0.55 & & & & & & $3(3.13 \%$ & & C \\
\hline (E) Suppliers of products or services & 2.08 & $15.7 \%$ & 0.75 & & & & & & & & D \\
\hline (F) Employees (if any) & 2.75 & $30.1 \%$ & 065 & & & & & & & & $F$ \\
\hline (G) Family members & 4.22 & $78.3 \%$ & 0.13 & 畩 & & & & & & 0 & G \\
\hline (H) Others & 2.30 & $14.5 \%$ & 0.59 & $\bar{\Delta}$ & & & & 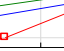 & & & $\mathrm{H}$ \\
\hline
\end{tabular}

1/ assessment in a scale from 1 to 5 , where 1 is not relevant and 5 is crucial. ${ }^{2 /}$ characteristics of clusters: cluster no. 1 (guest houses-38\%, lodgings-22\%, agritourist farms-28 $\%$, others-12\%), cluster no. 2 (guest houses- $46 \%$, lodgings- $27 \%$, agritourist farms- $12 \%$, others-15\%), cluster no. 3 (guest houses- $40 \%$, lodgings- $48 \%$, agritourist farms $-4 \%$, others- $8 \%$ ). 
The second place, with an average of 3.79, was assigned to customers/individual guests. About 2/3 of the respondents $(67.5 \%)$ gave notes 4 or 5 . The importance of customers/individual guests is visible between clusters, for FFs classified in clusters 1 and 2, the importance of customers/individual guests is higher (average above 4) than for FFs from cluster 3 (average 2.5). The third place, with an average of 2.75, was taken by employees. In the case of this group of stakeholders, differences between clusters are also visible. For FFs from cluster 2, the importance of employees in FFs activity is higher (average 4), while for FFs from cluster 1 and 3, it is lower (average 2.5 and below 2).

The importance of other stakeholder groups was rated lower, including other entrepreneurs from the same local area (mean 2.52), business customers (if any) and local authorities (2.19) and suppliers of products or services (2.08). Less than $20 \%$ of the FFs granted notes 4 and 5 for these stakeholder groups.

\subsection{Specific Features of FFs Providing Accommodation Services underlined in Promotional Activities}

The most important feature highlighted in the promotion of accommodation services provided by family businesses was hospitality (average 4.48 on the scale from 1 to 5 , where 1 means their complete omission and 5 a very strong emphasis on a feature (Table 6)). Over $85 \%$ of the surveyed FFs assigned this feature a note 4 or 5 . The next places were taken by the following: the unique mood of the place (average $4.38 ; 81.9 \%$ of 4 and 5 notes), good location (easy access) (4.32; 83.1\%), high level of service $(4.31 ; 85.5 \%)$, tourist attractions of the area $(4.31 ; 83.1 \%)$, kind and committed owners/operators (4.30: $80.7 \%)$, quiet and peacefulness of the surroundings $(4.29 ; 80.7 \%)$.

Cluster analysis showed the differences between the individual characteristics. For cluster no. 1, out of $53 \%$ of FFs, all studied characteristics were important (average 4 and above 4). Here, the highest rating was given to hospitality, the lowest for price attractiveness and good location (easy access). In cluster no. 2 (26.5\% of FFs), all features, with the exception of delicious food, turned out to be important in promoting accommodation services provided by FFs. On the other hand, in cluster no. 3 (20.5\% of FFs), most of the characteristics obtained average values in the range 3.0-3.6, with the average value for good location (easy access) and for kind and committed owners/operators achieving a value below 3.0. 
Table 6. Specific features underlined in promotional activities by FFs providing accommodation services.

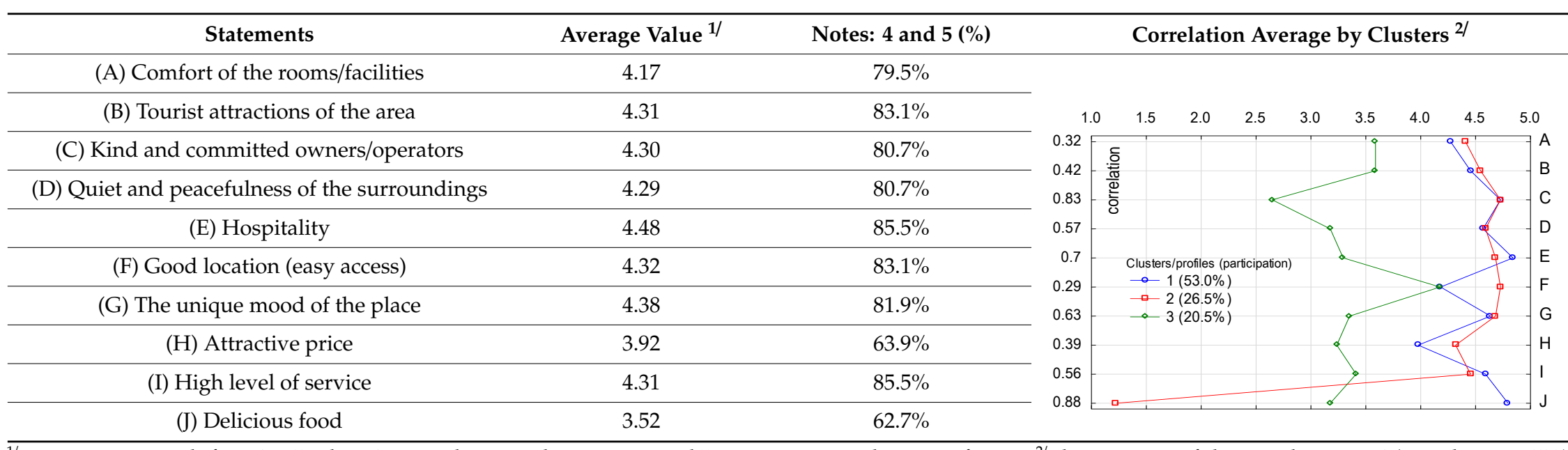

1/ assessment in a scale from 1 to 5 , where 1 means their complete omission and 5 a very strong emphasis on a feature. ${ }^{2 /}$ characteristics of clusters: cluster no. 1 (guest houses- $52 \%$, lodgings-14\%, agritourist farms-23\%, others- $11 \%$ ), cluster no. 2 (guest houses-9\%, lodgings-68\%, agritourist farms-5\%, others-18\%), cluster no. $3($ guest houses- $-53 \%$, lodgings-29\%, agritourist farms- $12 \%$, others- $6 \%$ ). 


\section{Discussion}

Our survey has shown that characteristics of family business give the opportunity to compete among companies providing accommodation services with a focus on the long-term perspective of the business development and the provision of high-quality services. This is particularly important as our research is focused on FFs providing accommodation services in the Polish accommodation sector, 30 years after the beginning of economic change. This meant a complete change in the way of thinking and approaching economic activity, a move away from a centrally planned economy and a transition to a private property-based economy. However, this did not happen immediately, and the process of privatization of the Polish economy continued over the following years, including its intensification and key economic reforms in the second half of the 1990s. The year 2004 and Poland's accession to the EU can be assumed as the end of economic transformation.

Therefore, the discussion of the results was based on these three specific features of FFs providing accommodation services in the Polish tourism sector. These are familiarity, long-term perspective and high level of service quality.

An important feature determining the functioning of FFs in the accommodation sector is familiarity. This sector is characterized by its dispersion in most tourist Polish regions. Apart from large hotels, there are many small companies offering accommodation. A significant number of them are FFs, established and run by the residents of a given local area. FFs have limited possibilities to compete with larger companies: they have smaller financial resources and less developed assets. However, their strength is their family character, and the resulting opportunities are the basis of their competitiveness. These companies are directly managed by the owners. They have the opportunity to create a conviction of hospitality and the unique mood. At the same time, there are relatively large opportunities to build relationships with clients based on the owner's person/family through direct meetings with tourists. In this aspect, familiarity can be considered as a basis for the competitive advantage of FFs' providing accommodation services. The literature highlights the importance of achieving a competitive advantage [102], especially for small enterprises [103]. Various possibilities were analyzed [101-104], including internal and external sources [102], i.e., human resources [105] and high quality [106]. In addition, other studies show that the contact of tourists with the owner can be seen as a valuable element of the trip [60]. As a result, tourists can develop such associations with the company, such as hospitality or trust, which are more difficult to create in the case of large hotel facilities and non-family businesses.

At the same time, a strategic approach to resources which are the basis of FFs should be indicated [8,24,104]. According to the model based on the Resource-Based View (RBV) [24,104], which combines family business and competitive advantage, there is a relationship between family inputs and family firm strategy and performance. Family inputs include its beliefs, practices, policies, philosophies and doctrines [24]. This can be analyzed as family orientation considered in five dimensions: tradition (roles/role identification, rituals and routines, shared history, shared meaning, and legacy), stability (homeostasis, predictable interaction patterns, rule-governed boundaries, permanence, resistance to change sanctions for unacceptable behavior), loyalty (sense of duty and obligation, sense of commitment, priority on togetherness, and sense of indebtedness), trust (safety, security, protection, fairness, reciprocity, and trustworthiness), and interdependency (reliance on one another, cohesion, emotional ties, and support of family members) [22]. Family inputs are assessed according to the four categories of resources (physical, human, organizational, and process). This allows to estimate the capabilities in light of the external competitive environment to look at how a sustainable competitive advantage can be achieved [24].

As a positive feature of the functioning of FFs in Poland 30 years after the political and economic transformation, it is important that the owners take into account the long-term perspective. This results from their responsibility for the fate of the family and investment of their own financial resources, and is also embedded in the change in thinking after the political transformation in Poland. 
The inclusion of a long-term approach is widely analyzed in the literature. Three elements of long-term orientation (continuity, community and reputation) are highlighted, and their moderating effects on the link between family ownership and sustainability practices are examined [51]. From a sample of Spanish FFs, findings show that long-term vision and the presence of nonfamily managers are positively related to entry modes involving stronger international commitment, although self-financing limits this commitment. In addition, in the context of a long-term strategic vision, a sense of loyalty, a stable culture, commitment, and pride in family tradition is emphasized [107]. The long-term perspective adopted by family members for the functioning of FFs results from investment and return on investment [107].

At the same time, the long-term perspective is analyzed from an internal and external perspective. The internal perspective refers to the ability to invest over a long period of time, and to achieve a satisfactory return on capital with a single reduction in risk factors associated with the activity. The external perspective indicates that it refers to stakeholder relations on the one hand, and on the other hand, it fits in the development of the region. The literature indicates that the functioning of FFs fits into the strategies of sustainable development of local communities through their operations, including the promotion of sustainable tourism, the local culture and products. Any action aimed at ensuring the sustainable development of a given region and small towns is crucial in terms of both environmental, social and economic importance. In particular, attention should be paid to undertaking economic activities that provide income for the local population, while at the same time ensuring the promotion of the region [108].

Our research has identified hospitality as the basis for the promotional activities of FFs. Research conducted in Switzerland indicates that family ownership positively influences the development of FF's image. This is due to the high expectations of family leaders to promote an FF's image and their risk-taking. This consequently determines performance companies [18]. This should also be analyzed in the context of the promotional activities undertaken by the surveyed FFs. The basis of promotional messages was hospitality along with the comfort of the facilities, high quality, high level of service, and the unique mood of the place. Other studies stressed that through the promotion of what FFs refer to as a family-based brand identity, a customer-centric orientation is fostered. This allows for a positive impact on firm performance [55]. This term, "family-based brand identity" [23,27,55,96], is also used in the literature to describe the family firms' ability to persuade consumers to make purchasing decisions based on the perceived attributes of the seller [55]. It allows for building such relational associations in marketing, and communication serves as a powerful signal, which could, and should, be used when promoting a family firm's offering, as it may help in building a favorable reputation and strong, positive and lasting customer relationships [45].

In summarizing the results achieved, it is important to underline those aspirations that show a balanced approach to FFs. The main points to be mentioned are taking into account the long-term perspective, paying attention to all stakeholders, caring for guests' needs and an individual approach.

Our study is important for the development of FFs in the accommodation services sector in Poland. First of all, it fills a gap in research on family businesses in Poland, as well as in research on companies providing accommodation services. Only one study commissioned by the Polish government has been conducted, 30 years ago, since the economic and political transformation. The importance of the results of our study is all the greater because this year, in the context of the COVID epidemic, there is talk of the need to develop sustainable tourism in rural areas. The research tool we have developed can be used to analyse FFs in other sectors of the economy or in relation to large companies. New research opportunities are related to the FFs situation due to a completely unpredictable event from the macro-environment (COVID-19).

We are aware that the size of the sample may be a limitation, but we draw attention to several issues. First of all, the structure of our sample corresponds to the structure of guesthouses, private accommodation and agritourism farms by voivodeship in Poland. Secondly, there is a very high reluctance of family business owners to give any answers, as evidenced by the fact that a government 
survey conducted over 10 years ago had a smaller sample of family businesses for the accommodation services sector. Thirdly, owners of most family businesses providing accommodation services are afraid of competition, all the more so because such activity is the main source of family income.

We are also aware that our results are based on the declarations of small FFs owners. They do not have to translate into real action. Therefore, the practices applied by the described companies in terms of exploiting their family character should be an interesting direction for further analyses. An important direction of future activities may also include such issues as crisis management, succession issues, role of strategic planning as well as the relationship between family ownership and firm performance. However, this will involve the use of in-depth qualitative interviews and will not be quantitative due to existing limitations. However, even more so, such a survey is necessary to increase the competitiveness of the regions, reduce disparities and ensure the development of sustainable tourism now, during, and after the pandemic.

\section{Conclusions}

Our survey has shown that the owners of FFs are aware of their familiarity assets, which implies some business activity. They take into account the family character when creating the company's image, which is important for individual customers. They try to stand out for their quality of service and hospitality, while having limited opportunities for development as small family businesses.

Managers in the surveyed companies were aware of their limitations in terms of creating the physical elements of their offer in comparison with larger facilities, as well as those that are not family businesses. At the same time, it should be remembered that the services are intangible. In connection with this feature, the companies in question have the opportunity to use the family character, building their image based on the owner's person/family and associations related to hospitality, trust, or by building relationships with customers. Such an action is all the more purposeful, as these features are more difficult to achieve for larger entities.

Author Contributions: H.G.-W. and M.D. designed the research tool and carried out the study; H.-G.W. designed the layout of this article; W.L. carried out the calculations; H.-G.W. and K.R. described the results; H.G.-W., M.D. and K.R. participated in the introduction and discussion of the results; M.D. wrote the conclusions. All authors have read and agreed to the published version of the manuscript.

Funding: The Article Processing Charge was financed by the Polish Ministry of Science and Higher Education for maintaining research potential and for scientific research for the Institute of Human Nutrition, Warsaw University of Life Sciences and the University of Social Sciences

Conflicts of Interest: The authors declare no conflict of interest.

\section{References}

1. Mandl, I. Overview of Family Business Relevant Issues Contract No. 30-CE-0164021/00-51 Final Report; Austriam Institute for SME Research: Vienna, Austria, 2008; pp. 1-175.

2. Harms, H. Review of Family Business Definitions: Cluster Approach and Implications of Heterogeneous Application for Family Business Research. Int. J. Financ. Stud. 2014, 2, 280-314. [CrossRef]

3. Chua, J.H.; Chrisman, J.J.; Sharma, P. Defining the Family Business by Behavior. Entrep. Theory Pract. 1999, 23, 19-39. [CrossRef]

4. Zellweger, T.M.; Eddleston, K.A.; Kellermanns, F.W. Exploring the concept of familiness: Introducing family firm identity. J. Fam. Bus. Strateg. 2010, 1, 54-63. [CrossRef]

5. Chrisman, J.J.; Chua, J.H.; Steier, L.P. An introduction to theories of family business. J. Bus. Ventur. 2003, 18, 441-448. [CrossRef]

6. Botero, I.C.; Cruz, C.; De Massis, A.; Nordqvist, M. Family business research in the European context. Eur. J. Int. Manag. 2015, 9, 139-159. [CrossRef]

7. Pongelli, C.; Calabrò, A.; Basco, R. Family firms' international make-or-buy decisions: Captive offshoring, offshore outsourcing, and the role of home region focus. J. Bus. Res. 2019, 103, 596-606. [CrossRef]

8. Chrisman, J.J.; Chua, J.H.; Sharma, P. Trends and directions in the development of a strategic management theory of the family firm. Entrep. Theory Pract. 2005, 29, 555-575. [CrossRef] 
9. Pounder, P. Family business insights: An overview of the literature. J. Fam. Bus. Manag. 2015, 5, 116-127. [CrossRef]

10. Bertrand, M.; Schoar, A. The role of family in family firms. J. Econ. Perspect. 2006, 20, 73-96. [CrossRef]

11. Stafford, K.; Duncan, K.A.; Dane, S.; Winter, M. A research model of sustainable family businesses. Fam. Bus. Rev. 1999, 12, 197-208. [CrossRef]

12. Dyer, W.G.; Dyer, W.J. Putting the family into family business research. Fam. Bus. Rev. 2009, 22, $216-219$. [CrossRef]

13. Dyer, G.W.; Whetten, D.A. Family firms and social responsibility: Preliminary evidence from the S \& P 500. Entrep. Theory Pract. 2006, 30, 785-802.

14. Hauck, J.; Suess-Reyes, J.; Beck, S.; Prügl, R.; Frank, H. Measuring socioemotional wealth in family-owned and -managed firms: A validation and short form of the FIBER Scale. J. Fam. Bus. Strateg. 2016, 7, 133-148. [CrossRef]

15. Memili, E.; Eddleston, K.A.; Kellermanns, F.W.; Zellweger, T.M.; Barnett, T. The critical path to family firm success through entrepreneurial risk taking and image. J. Fam. Bus. Strateg. 2010, 1, 200-209. [CrossRef]

16. Sorenson, R.L.; Bierman, L. Family capital, family business, and free enterprise. Fam. Bus. Rev. 2009, 22, 193-195. [CrossRef]

17. Herrero, I.; Hughes, M. When family social capital is too much of a good thing. J. Fam. Bus. Strateg. 2019, 10, 100271. [CrossRef]

18. Ng, P.Y.; Dayan, M.; Di Benedetto, A. Performance in family firm: Influences of socioemotional wealth and managerial capabilities. J. Bus. Res. 2019, 102, 178-190. [CrossRef]

19. Boers, B.; Ljungkvist, T.; Brunninge, O.; Nordqvist, M. Going private: A socioemotional wealth perspective on why family controlled companies decide to leave the stock-exchange. J. Fam. Bus. Strateg. 2017, 8, 74-86. [CrossRef]

20. Morgan, T.J.; Gomez-Mejia, L.R. Hooked on a feeling: The affective component of socioemotional wealth in family firms. J. Fam. Bus. Strateg. 2014, 5, 280-288. [CrossRef]

21. Hirigoyen, G.; Poulain-Rehm, T. The Corporate Social Responsibility of Family Businesses: An International Approach. Int. J. Financ. Stud. 2014, 2, 240-265. [CrossRef]

22. Lumpkin, G.T.; Martin, W.; Vaughn, M. Family orientation: Individual-level influences on family firm outcomes. Fam. Bus. Rev. 2008, 21, 127-138. [CrossRef]

23. Gallucci, C.; Santulli, R.; Calabrò, A. Does family involvement foster or hinder firm performance? The missing role of family-based branding strategies. J. Fam. Bus. Strateg. 2015, 6, 155-165. [CrossRef]

24. Habbershon, T.G.; Williams, M.L. A resource-based framework for assessing the strategic advantages of family firms. Fam. Bus. Rev. 1999, 12, 1-25. [CrossRef]

25. Barros, I.; Hernangómez, J.; Martin-Cruz, N. A theoretical model of strategic management of family firms. A dynamic capabilities approach. J. Fam. Bus. Strateg. 2016, 7, 149-159. [CrossRef]

26. Astrachan, J.H. Strategy in family business: Toward a multidimensional research agenda. J. Fam. Bus. Strateg. 2010, 1, 6-14. [CrossRef]

27. Krappe, A.; Goutas, L.; von Schlippe, A. The "family business brand": An enquiry into the construction of the image of family businesses. J. Fam. Bus. Manag. 2011, 1, 37-46. [CrossRef]

28. Presas, P.; Mũoz, D.; Guia, J. Branding familiness in tourism family firms. J. Brand Manag. 2011, 18, $274-284$. [CrossRef]

29. Babin, B.J.; Binz Astrachan, C.; Botero, I.C.; Hair, J.F.; Prügl, R.; Herrmann, J.-L.; Laroche, M.; Sarstedt, M. From Family Identity to Family Firm Image and Reputation: Exploring Facets of the Perception of Family Influence in Branding, Marketing, and Other Messaging. J. Fam. Bus. Strateg. 2017, 8, I-III. [CrossRef]

30. Kowalewska, A.; Szut, J.; Małgorzata, B.L.; Kwiatkowska, M.; Sułkowski, Ł.; Marjański, A.; Krynicki, T.J. Firmy Rodzinne w Polskiej Gospodarce-Szanse $i$ Wyzwania; Polish Agency of Enterprise Development: Warsaw, Poland, 2009.

31. Kozłowska, M. Europejskie kraje postsocjalistyczne-Kraje zakończonej transformacji systemowej. Pr. Nauk. Uniw. Ekon. Katowicach 2011, 101-117.

32. Havrylyshyn, B.O.; Meng, X.; Tupy, M.L. Policy Analysis. 25 Years of Reforms in Ex-Communist Countries Fast and Extensive Reforms Led to Higher Growth and More Political Freedom. 2016. Available online: https://www.cato.org/publications/policy-analysis/25-years-reforms-ex-communistcountries-fast-extensive-reforms-led (accessed on 23 July 2020). 
33. Onas-FBN Poland-Stowarzyszenie Firm Rodzinnych. Available online: https://fbnpoland.org/o-nas.html (accessed on 23 July 2020).

34. Family Business Statistics. Available online: www.europeanfamilybusinesses.eu (accessed on 23 July 2020).

35. Family Businesses in Europe-Tuesday, 8 September 2015. Available online: https://www.europarl.europa. eu/doceo/document/TA-8-2015-0290_EN.html (accessed on 23 July 2020).

36. Family Business Yearbook. 2017. Available online: https://familybusiness.ey-vx.com/fb-yearbook-flipbook2017/mobile/index.html\#p=1 (accessed on 23 July 2020).

37. Miller, D.; Breton-Miller, I.L.; Lester, R.H.; Cannella, A.A. Are family firms really superior performers? J. Corp. Financ. 2007, 13, 829-858. [CrossRef]

38. De Massis, A.; Chua, J.; Kotlar, J. State of the art of family business research. In Family Business Studies: An Annotated Bibliography; De Massis, A., Sharma, P., Chua, J.H., Chrisman, J.J., Eds.; Edward Elgar Publishing: Cheltenham, UK, 2012; pp. 10-46.

39. European Commission. Final Report of the Expert Group: Overview of Family-Business-Relevant Issues: Research, Networks, Policy Measures and Existing Studies; European Commission: Brussels, Belgium, 2007.

40. Parliament, E. REPORT on Family Businesses in Europe. (2014/2210 (INI)). Committee on Industry, Research and Energy, 30 June 2015, A8-0223/2015. Available online: https://www.europarl.europa.eu/doceo/document/ A-8-2015-0223_EN.html (accessed on 11 August 2020).

41. Popczyk, W. Again on the definition of a family business. Relacje. Mag. Firm Rodz. 2016, 6, 7-9.

42. Ward, J.L. The Special Role of Strategic Planning for Family Businesses. Fam. Bus. Rev. 1988, 1, $105-117$. [CrossRef]

43. Tokarczyk, J.; Hansen, E.; Green, M.; Down, J. A resource-based view and market orientation theory examination of the role of "familiness" in family business success. Fam. Bus. Rev. 2007, 20, 17-31. [CrossRef]

44. Irava, W.J.; Moores, K. Clarifying the strategic advantage of familiness: Unbundling its dimensions and highlighting its paradoxes. J. Fam. Bus. Strateg. 2010, 1, 131-144. [CrossRef]

45. Binz, C.; Hair, J.F.; Pieper, T.M.; Baldauf, A. Exploring the effect of distinct family firm reputation on consumers' preferences. J. Fam. Bus. Strateg. 2013, 4, 3-11. [CrossRef]

46. Frank, H.; Lueger, M.; Nosé, L.; Suchy, D. The concept of "Familiness": Literature review and systems theory-based reflections. J. Fam. Bus. Strateg. 2010, 1, 119-130. [CrossRef]

47. Erdem, F.; Gül Başer, G. Family and business values of regional family firms: A qualitative research. Int. J. Islam. Middle East. Financ. Manag. 2010, 3, 47-64. [CrossRef]

48. Carrigan, M.; Buckley, J. 'What's so special about family business?' An exploratory study of UK and Irish consumer experiences of family businesses. Int. J. Consum. Stud. 2008, 32, 656-666. [CrossRef]

49. Arregle, J.-L.; Hitt, M.A.; Sirmon, D.G.; Very, P. The Development of Organizational Social Capital: Attributes of Family Firms. J. Manag. Stud. 2007, 44, 73-95. [CrossRef]

50. Radu Lefebvre, M.; Lefebvre, V. Anticipating intergenerational management transfer of family firms: A typology of next generation's future leadership projections. Futures 2016, 75, 66-82. [CrossRef]

51. Memili, E.; Fang, H.C.; Koç, B.; Yildirim-Öktem, Ö.; Sonmez, S. Sustainability practices of family firms: The interplay between family ownership and long-term orientation. J. Sustain. Tour. 2018, 26, 9-28. [CrossRef]

52. Chrisman, J.J.; Chua, J.H.; Pearson, A.W.; Barnett, T. Family Involvement, Family Influence, and Family-Centered Non-Economic Goals in Small Firms. Entrep. Theory Pract. 2012, 36, 267-293. [CrossRef]

53. Sharma, P.; Sharma, S. Drivers of Proactive Environmental Strategy in Family Firms. Bus. Ethics Q. 2011, 21, 309-334. [CrossRef]

54. Deephouse, D.L.; Jaskiewicz, P. Do Family Firms Have Better Reputations Than Non-Family Firms? An Integration of Socioemotional Wealth and Social Identity Theories. J. Manag. Stud. 2013, 50, 337-360. [CrossRef]

55. Craig, J.; Dibrell, C.; Davis, P. Leveraging Family-Based Brand Identity to Enhance Firm. J. Small Bus. Manag. 2008, 46, 351-371. [CrossRef]

56. Luo, A.; Kumar, V. Recovering hidden buyer-seller relationship states to measure the return on marketing investment in business-tobusiness markets. J. Mark. Res. 2013, 50, 143-160. [CrossRef]

57. Narus, J.A.; Anderson, J.C. Partnering as a Focused Market Strategy. Calif. Manag. Rev. 1991, 33, 95-113. 
58. De Wulf, K.; Odekerken-Schröder, G.; Iacobucci, D. Investments in consumer relationships: A cross-country and cross-industry exploration. J. Mark. 2001, 65, 33-50. [CrossRef]

59. Zhang, J.Z.; Watson, G.F.; Palmatier, R.W.; Dant, R.P. Dynamic Relationship Marketing. J. Mark. 2016, 80, 53-75. [CrossRef]

60. Presas, P.; Guia, J.; Muñoz, D. Customer's Perception of Familiness in Travel Experiences. J. Travel Tour. Mark. 2014, 31, 147-161. [CrossRef]

61. Núñez-Cacho, P.; Molina-Moreno, V.; Corpas-Iglesias, F.A.; Cortés-García, F.J. Family businesses transitioning to a circular economy model: The case of "Mercadona". Sustainability 2018, 10, 538. [CrossRef]

62. Kallmuenzer, A.; Nikolakis, W.; Peters, M.; Zanon, J. Trade-offs between dimensions of sustainability: Exploratory evidence from family firms in rural tourism regions. J. Sustain. Tour. 2018, 26, 1204-1221. [CrossRef]

63. Sampaio, A.R.; Thomas, R.; Font, X. Why are Some Engaged and Not Others? Explaining Environmental Engagement among Small Firms in Tourism. Int. J. Tour. Res. 2012, 14, 235-249. [CrossRef]

64. Hernández-Perlines, F.; Rung-Hoch, N. Sustainable entrepreneurial orientation in family firms. Sustainability 2017, 9, 1212. [CrossRef]

65. López-Pérez, M.E.; Melero-Polo, I.; Vázquez-Carrasco, R.; Cambra-Fierro, J. Sustainability and business outcomes in the context of SMEs: Comparing family firms vs. non-family firms. Sustainability 2018, 10, 4080. [CrossRef]

66. Marjański, A.; Marjańska, J. Uwarunkowania strategii małych i średnich przedsiębiorstw rodzinnych. Przedsiębiorczość Zarz. 2011, 12, 44-57.

67. Winnicka-Popczyk, A. Rozwój zainteresowania firmami rodzinnymi w Polsce a proces wspierania ich dzialalności. Przedsiębiorczość Zarz. 2011, 12, 190-201.

68. Małyszek, E. Czynniki wpływające na sukces i długoterminowe przetrwanie firm rodzinnych. Przedsiębiorczość Zarz. 2011, 12, 82-96.

69. Kempa, E. Strategia rozwoju firm rodzinnych w sektorze MMSP. Przedsiębiorczość Zarz. 2011, 12, 73-81.

70. Dębski, M.; Górska-Warsewicz, H.; Skalska, T. Family-based Brand Equity in the Hospitality Industry. Pr. Nauk. Uniw. Ekon. Wroctawiu. Res. Pap. Wroclaw Univ. Econ. Bus. 2019, 63, 161-175.

71. The Civil Law. Dz.U. 2018 poz. 1025 OBWIESZCZENIE; Polish Goverment: Warsaw, Poland, 2018; pp. 1-35.

72. Rocznik Statystyczny Województwa Dolnoślaskiego Statistical Yearbook of Dolnoślaskie Voivodship; Statistical Office: Wrocław, Poland, 2019.

73. Rocznik Statystyczny Województwa Mazowieckiego Statistical Yearbook of Mazowieckiego Voivodship; Statistical Office: Warszawa, Poland, 2019.

74. Rocznik Statystyczny Województwa Małopolskie Statistical Yearbook of Małopolskie Voivodship; Statistical Office: Kraków, Poland, 2019.

75. Rocznik Statystyczny Województwa Świętokrzyskie Statistical Yearbook of Świętokrzyskie Voivodship; Statistical Office: Kielce, Poland, 2019.

76. Rocznik Statystyczny Województwa Warmińsko-mazurskie Statistical Yearbook of Warmińsko-mazurskie Voivodship; Statistical Office: Olsztyn, Poland, 2019.

77. Rocznik Statystyczny Województwa Łódzkie Statistical Yearbook of Łódzkie Voivodship; Statistical Office: Łodź, Poland, 2019.

78. Rocznik Statystyczny Województwa Lubuskiego Statistical Yearbook of Lubuskie Voivodship; Statistical Office: Zielona Góra, Poland, 2019.

79. Rocznik Statystyczny Województwa Kujawsko-Pomorskiego Statistical Yearbook of Kujawsko-Pomorskie Voivodship; Statistical Office: Bydgoszcz, Poland, 2019.

80. Rocznik Statystyczny Województwa Opolskie Statistical Yearbook of Opolskie Voivodship; Statistical Office: Opole, Poland, 2019.

81. Rocznik Statystyczny Województwa Podkarpackie Statistical Yearbook of Podkarpackie Voivodship; Statistical Office: Rzeszów, Poland, 2019.

82. Rocznik Statystyczny Województwa Pomorskie Statistical Yearbook of Pomorskie Voivodship; Statistical Office: Gdańsk, Poland, 2019. 
83. Rocznik Statystyczny Województwa Ślaskie Statistical Yearbook of Ślaskie Voivodship; Statistical Office: Katowice, Poland, 2019.

84. Rocznik Statystyczny Województwa Zachodniopomorskiego Statistical Yearbook of Zachodniopomorskie Voivodship; Statistical Office: Szczecin, Poland, 2019.

85. Mendy, J.; Rahman, M.; Bal, P.M. Using the "best-fit" approach to investigate the effects of politico-economic and social barriers on SMEs' internationalization in an emerging country context: Implications and future directions. Thunderbird Int. Bus. Rev. 2020, 62, 199-211. [CrossRef]

86. Claver, E.; Rienda, L.; Quer, D. Family Firms' International Commitment: The Influence of Family-Related Factors. Fam. Bus. Rev. 2009, 22, 125-135. [CrossRef]

87. Upton, N.; Teal, E.J.; Felan, J.T. Strategic and business planning practices of fast growth family firms. J. Small Bus. Manag. 2001, 39, 60-72. [CrossRef]

88. Bartholomeusz, S.; Tanewski, G.A. The relationship between family firms and corporate governance. J. Small Bus. Manag. 2006, 44, 245-267. [CrossRef]

89. Micelotta, E.R.; Raynard, M. Concealing or Revealing the Family? Fam. Bus. Rev. 2011, 24, $197-216$. [CrossRef]

90. Martínez, J.I.; Stöhr, B.S.; Quiroga, B.F. Family Ownership and Firm Performance: Evidence From Public Companies in Chile. Fam. Bus. Rev. 2007, 20, 83-94. [CrossRef]

91. Setia-Atmaja, L.; Haman, J.; Tanewski, G. The role of board independence in mitigating agency problem II in Australian family firms. Br. Account. Rev. 2011, 43, 230-246. [CrossRef]

92. Filling the Institutional Void: The Social Behavior and Performance of Family Versus Non-Family Technology Firms in Emerging Markets: Handbook of Research on Family Business, Second Edition. Available online: https://www.elgaronline.com/view/edcoll/9781848443228/9781848443228.00009.xml (accessed on 11 May 2020).

93. Baruch, Y.; Holtom, B.C. Survey response rate levels and trends in organizational research. Hum. Relat. 2008, 61, 1139-1160. [CrossRef]

94. Af Wåhlberg, A.E.; Poom, L. An Empirical Test of Nonresponse Bias in Internet Surveys. Basic Appl. Soc. Psych. 2015, 37, 336-347. [CrossRef]

95. Carley-Baxter, L.R.; Hill, C.A.; Roe, D.J.; Twiddy, S.E.; Baxter, R.K.; Ruppenkamp, J. Does Response Rate Matter? Journal Editors Use of Survey Quality Measures in Manuscript Publication Decisions. Surv. Pract. 2009, 2, 1-7. [CrossRef]

96. Cabrera-Suárez, M.K.; De la Cruz Déniz-Déniz, M.; Martín-Santana, J.D. Familiness and market orientation: A stakeholder approach. J. Fam. Bus. Strateg. 2011, 2, 34-42. [CrossRef]

97. Poza, E.J.; Alfred, T.; Maheshwari, A. Stakeholder Perceptions of Culture and Management Practices in Family and Family Firms-A Preliminary Report. Fam. Bus. Rev. 1997, 10, 135-155. [CrossRef]

98. Rojas, R. Kohonen Networks 15.1. In Neural Networks; Springer: Berlin, Germany, 1996; pp. $391-412$. ISBN 9783540605058.

99. Stastny, J.; Turcinek, P.; Motycka, A. Using Neural Networks for Marketing Research Data Classification. In Proceedings of the 10th WSEAS International Conference Data Networks Communications Computer, Catania, Italy, 29-31 May 2010; pp. 252-256.

100. Wilks, D.S. Cluster Analysis. Int. Geophys. 2011, 100, 603-616.

101. Sinharay, S. An overview of statistics in education. In International Encyclopedia of Education; Elsevier Ltd.: Amsterdam, The Netherlands, 2010; pp. 1-11. ISBN 9780080448947.

102. Barney, J.B. Firm Resources and Sustained Competitive Advantage. J. Manag. 1991, 17, 99-120. [CrossRef]

103. Smith, J.L.; Flanagan, W.G. Creating Competitive Advantage: Give Customers a Reason to Choose You over Your Competitors; Currency/Doubleday: New York, NY, USA, 2006; ISBN 9780385517096.

104. Grant, R.M. The Resource-Based Theory of Competitive Advantage: Implications for Strategy Formulation. Calif. Manag. Rev. 1991, 33, 114-135. [CrossRef]

105. Wang, W.-C.; Lin, C.-H.; Chu, Y.-C. Types of Competitive Advantage and Analysis. Int. J. Bus. Manag. 2011, 6,6 .

106. Morgan, N.; Piercy, N. Competitive Advantage, Quality Strategy and the Role of Marketing. Br. J. Manag. 1996, 7, 231-245. [CrossRef] 
107. Zehrer, A. Management of change in tourism-The problem of family internal succession in family-run tourism smes julia Haslwanter OberhauserGFB Hotel \& Tourismus Consulting GmbH. J. Fam. Bus. Stud. 2010, 4, 147-162.

108. Spröte, W. ECOSOC-Economic And Social Council. In A Concise Encyclopedia of the United Nations; ECOSOC: New York, NY, USA, 2010; pp. 147-152. [CrossRef]

Publisher's Note: MDPI stays neutral with regard to jurisdictional claims in published maps and institutional affiliations.

(C) 2020 by the authors. Licensee MDPI, Basel, Switzerland. This article is an open access article distributed under the terms and conditions of the Creative Commons Attribution (CC BY) license (http://creativecommons.org/licenses/by/4.0/). 